\title{
A Causal Relationship between (Nation Branding Dimension) Exports and Foreign Direct Investments, and Economic Growth for Saudi Arabia: A Panel Data Approach
}

\author{
Aftab Alam \\ College of Business Administration King Saud University Riyadh Saudi Arabia
}

Doi:10.5901/mjss.2016.v7n5p52

\begin{abstract}
Nation Brand Dimension Export is the largest source of Foreign Direct Investment (FDI) inflow for the developing countries of the world. This study examines the short and long run relationship between Export, FDI growth for kin by employing the Unit Root test Autoregressive and Distributed Lags (ARDL) approach in the time series framework from 1980 to 2013. Augmented Dickey Fuller (ADF) test applied for checking the stationary or non-stationary of data, while ARDL technique applied for the presence of co-integration. Long run and short run relationship among macroeconomic variables in case of Saudi Arabia. Granger causality test also applied for future forecasting between export and FDI
\end{abstract}

\section{Introduction}

The importance of Nation Branding Dimension exports and FDI has been increasing with the passage of time. Now in the age of globalization and those countries who are recognize as the world leaders in the usual times are improving their economies through increasing trade aimed at mutual benefits. The present structure of countries to trade with other nations is not a prompt process. Different nation's skilled dissimilar circumstances with international trade depending upon their factor of skills.

As arisen in the history of the emerging world, nations had Import Replacement strategies in the late 1960s as well as in the early 1970s are seeing international trade between countries (based on their imperfect specialty) suggestively and positively. They are gaining benefits of joint trading, raises of relations, sensible prices and market growths. Exports and FDI measured as the main development enhancing factors for the growth of the economy. FDI is one of the most significant tools, which make countries particularly the emerging ones to achieve the investment levels outside their levels of saving because every nation has incomplete opportunities to grow and save in financial condition. In this period, it is impossible for every country to close their border for outside trade. The influences of these issues are multidimensional and they have impacts on common person whether they are social, political, economic or cultural. WTO (world trade organization) has now internationally trade supervision values and rule regulation for international trade. Kingdom of Saudi Arabia (a developing country) having complications of low productivity and underutilization of resources due to nonspecialization and diseconomies of scale in different sectors of the economy like industry etc. from literature there are many scholars in favor the positive impact of global trade and FDI inflows. The increasing internationally trade all over the world has run to the increasing competition to attract FDI in the emerging countries example from China

The growth of export states that export are the one of most important tools for accelerating factors for FDI. Through FDI, nations get more benefit by the effective use of their productive resources. Whether they human capital or natural resources of the host country. With modern technology host country can take more benefits, improved production levels, promote human capital and physically resources as well, but also have unclear impacts on social and cultural values. The act of exports shows the country's skill to sell goods and services produce in a host country to other nations in the world.

Exports from Kingdom of Saudi Arabia in 2014 amounted to US\$347.9 billion, up 38.5\% since 2010. Top exports of Saudi Arabia values for its international deliveries accounted for $97.6 \%$ of the over all. International Monetary Funds (IMF) world statically database viewpoint, Saudi Arabia total GDP was \$ 1.66 trillion in 2014. In the total Saudi economy, export is $21.5 \%$ participate. Continental wise perceptive export with Europe 13\%, 24\% to North America and Canada, $60 \%$ Asian countries and 3\% to African countries. Total population of Saudi Arabia 27.8 million, in 2014 its total export was $\$ 347.9$ billion

Saudi Arabia tops export was in 2014, Oils of total export was $85.1 \%$, Plastics was $5.7 \%$, Organic Chemical was 4.6\%, Fertilizer was $0.6 \%$, Aluminums was $0.4 \%$, Precious Metals, Coins and Gems was $0.3 \%$, Inorganic chemicals $0.3 \%$, Dairy Products $0.2 \%$, Copper Elements $0.2 \%$ and Steel and Iron Products $0.2 \%$. In elements, copper is fast growing export in classes up $745.3 \%$ for last five years, and second element improving its export inorganic chemicals 
(petro chemical) which increased $211.6 \%$. Saudi Aluminum is third export is in third place which in $173.6 \%$. The fastest increasing export is Saudi iron or steel.

Exports of Saudi Arabia reduced to 185284 million Saudi Arabia Riyal in 2015 to 218996 million Saudi Arabia Riyal in mid of 2015. Saudi Arabia export be around 227542.58 million Saudi Arabia Riyal from 1968 to 2015, reaching an alltime high of 677144 million Saudi Arabia Riyal in the last of 2005 and a record low of 9118 million Saudi Arabia Riyal in the last sector of 1968. Exports in Saudi Arabia is report by the Saudi Arabian Monetary Agency (SAMAA).

Currently, FDI flow in Saudi Arabia is downward. According to UNCTAD, report, which is publish in 2015 Saudi Arabia, is third largest country for FDI after Turkey and United Arab Emirate in Western Asia after 2013. Eight billons is decline in $9.6 \%$ foreign flow in 2014. The little bit social tensions and political, finical and neighbored war and policy "began in 2011 and a domestic labor force and Saudisation," which started in 2011 and helps' to a local labor force, have all been problems for FDI

The Government of Saudi Arabia recently announced retailer and whole sectors with hundred percent foreign retained. The authorities welcome to FDI due to its ability and technology transfer use and from the national work to promote monetary growth and improve the local assets. The country under control of inflations and moderately stable exchange rate that opening to foreign capital in gas and natural resources, and as well as programs are inclusive privatization profit to investors in country. The self-motivated performance of financial sectors. In conclusion, access to the world oil reserves crucial factors for foreign investors are very low energy cost and a high standard of living

\section{Review of Literature}

Numerous academic studies done and carried out to investigate the empirical relationship between export and Foreign Direct Investment (FDI) and economic growth in Saudi Arabia and rest of the world, an our views such studies finding below

In this research paper, we found a proposed model of trade, level of FDI and export supporting FDI (EsFDI), EsFDI decrease the distribution cost abroad while production are remain at home country, EsFDI reciprocity between Export and Foreign Direct Investment (FDI). Whole export and production abroad remain substitute (Krautheim, S.2013). Finding of this study suggest that decision of initial costs play an important role Export and Foreign Direct Investment. Which productivity and the dominant effect appear in the Japan that in other countries. The effect of firm size and its export affect FDI of host country (Todo, Y. 2011).

Nation Branding dimension Export and Foreign Direct Investment (FDI) have significant relation, export play a vital role for FDI if it properly improve. Through export a country will attract FDI the good example from china (Alam, at al 2013). Founding from this research supply of export, export of locally demand high of price is reduce of demand and price of low commodity increase its demand supply. Foreign direct Investment have no statically affected export significantly performance but the coefficient has positive sign of FDI on export (Sharma, K. 2000).

In this Paper we found that FDI and FDI bidirectional applies causality, though export Granger cause FDI. The result show some indication that Export playing a leading role in the development of FDI from western china. However, the growth of full potential capital investment in infrastructure projects before the domestic region released in china. The finding conclusion about this article that FDI state may be reflect an early stage of export development process (Zhang, Q at all 2001). It found that export and FDI have strong and positive effect on economic growth. The results propose that two growth and policies adopted in China are useful for other emerging and intermediate economics. The promotion of export adopt of world technology and business practices and effect on FDI (Yao, S. 2006)

Founding from a study authors use multiple regression and he found the there is strong and positive impact of FDI on South Korea economics growth. Furthermore, more from this study shows that human capital, employment and export have positive and significant impact on FDI. While locally, investment has no significant on South Korean economics growth. (Koojaroenprasit, S. 2012). Saudi Arabia has oil-based economy with strong government hold on economic control activities, Saudi Arabia hold $29 \%$ of oil reserves of the world. Saudi Arabia is the largest world exporter of oil and petrochemicals to all over the world. Saudi petro chemical will play a vital role for attract of FDI (Alam, et al 2012). Founding from this research manuscript export and FDI have relationship, this relationship depend on country export if the country export will increase so it direct effect on country FDI. The authors discussed the export of Pakistan textile industries is increase so through export they will attract FDI to the host country (Khan, et al 2010),

Founding from this study providing evidence in the favor of the FDI idea is seem to be the main sources influencing economics performance in the country. Furthermore, there is positive causal relationship between export and FDI, from conclusion Export suggest a kind role for FDI led to export growth is linkage and could be representative that the incorporation of Mexico economy (Alguacil, M. T. at al 2002). This paper highlight that export modifications impact on 
Foreign Direct Investment (FDI) for a developing country. Export may led through Foreign Direct Investment (FDI) of the host country if it is positively affect export intensity of industries that have low share in world. Circuitously, Foreign Direct Investment (FDI) may boost export modification through spillover effects: that is, the presences of Foreign Direct Investment (FDI) in industries may be increase the export strength of local firms (Banga, R. 2006)

From this research, we found that FDI is one of major's factors to lashing the rapid export growth in Vietnam. From empirical analysis shown that $1 \%$ increase FDI inflows will be expect to give rise to $0.13 \%$ in Vietnam export to other countries (Xuan, N. T. at al 2008). ) In this paper we found the scholar tried to discuss Nation Branding(NB) dimension Export is a main tools for Foreign Direct Investment (FDI) in Pakistan, and to high light the main issues and interrelationship between Nation Branding(NB) dimension Export and Foreign Direct Invest in Pakistan (Alam, et al 2013).

We found strong indication based on three calculations that Foreign Direct Investment (FDI) and exports, exert have significant and positive influence on economic growth in the long run relationship. Finding from Granger Causality tests specify that there is long run relationship between Exports and Foreign Direct Investment (FDI) to economic development in Jordan. It is important that policy-maker in kingdom of Jordan to solve the problems to Foreign Direct Investment inflow and improve capacity to gain positive impact (Sami, J., \& Kreishan, F. 2012).

In this research the author recommended and focused on more liberal and reforms policies that enable and create environment for Foreign Direct Investment (FDI) inflow and export growth thereby reducing barriers in Nigeria. Export and FDI have positive relationship and through export Nigeria will attract more Foreign Direct Investment (FDI). Export and Foreign Direct Investment (FDI) dependent on each other's, between Export and FDI have direct relationship (Babalola, et al 2012).

Finding from this study export performance and export decision in Ghana manufacturing sectors on Panel data from (1991-2002) using some statically tools and result shows that Export and Foreign Direct Investment (FDI) have positive effect on firms, clearly the result of this study indicated that Export and Foreign Direct Investment (FDI) is very relevant and influencing on Ghana firms performance. Export and Foreign Direct Investment (FDI) have significant relationship (Abor, et al 2008)

\section{Research Frame Work}

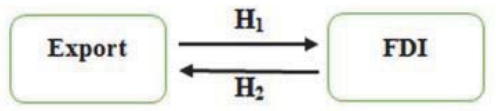

\section{Hypotheses}

$\mathrm{H}_{1:}$ There is any Relationship between Export and Foreign Direct Investment (FDI)

$\mathrm{H}_{2:}$ There is any Relationship between Foreign Direct Investment (FDI) and Export

\section{Objective of the Study}

To find out the relationship between Export and Foreign Direct Investment (FDI). What is the impact of Export on Foreign Direct Investment (FDI) and Foreign Direct Investment (FDI) effect on Export? The key factors of this study is to mention the optimal ways in which Kingdom of Saudi Arabia would improve Exports and attract Foreign Direct Investment (FDI). As a nation by bearing in mind, the different influences that can used to increase its export and attract Foreign Direct Investment (FDI). An exclusive uniqueness for itself among the nations of world and to use locating as a source for attracting Foreign Direct Investment (FDI) in Kingdom of Saudi Arabia. Our main objectives to find out the impact of export on Foreign Direct Investment (FDI) for short and long terms its relationship

\section{Data and Methodology}

Monthly vise data collected from index mundi from (1980 to 2013), this data taken from the index mundi and SAMA. 1980 to 2013. Foreign Direct Investment FDI in flow 1980 was 3192313000 \$ and 1981 was 6498136000 \$ and 1982 it was 11128380000. From 1983 to 2004 it increased little bit but from 2004 to 2012 it increased to 12182370000 \$. In addition, 2013 it decreased to 9297694000 \$. Export of Saudi Arabia in 1980 was 104411000000 \$ and 1981 was 115770000000 \$, in 1982 was $77740800000 \$$. In 2009, it was 202056000000 \$, in 2010 it was 261831000000 \$, in 2011 it was 376224000000 \$, in 2012 it was $399420000000 \$$ but in 2013 was decreased to $387616000000 \$$. 
The workhorse of this study is the vector auto regression model as it envelopes most of the Characteristics of the data (Babic, 2000). To analyze the impact of Export (National Brand Dimensions) influence on FDI in Saudi Arabia, VAR (vector auto regression) model is use for this purpose for time series analysis.

\subsection{Stationary and Non-Stationary Test for Export (Nation Branding Dimensions):}

In E-views for stationary and non- stationary test, we will go to unit root test (Augmented Dickey-Fuller test statistic) Total Export (Nation Branding Dimensions) at first level it not stationary but at first difference it stationary (Result in Below Table) $p$ value is 0.000 at $.01 \%$ it significant

Table:1 Null Hypothesis: D(EXPORT) has a unit root

Exogenous: Constant

Lag Length: 12 (Automatic - based on SIC, maxlag=17)

\begin{tabular}{llrr}
\hline \hline & & t-Statistic & Prob. $^{*}$ \\
\hline \hline Augmented Dickey-Fuller test statistic & & -5.783743 & 0.0000 \\
\hline Test critical values: & 1\% level & -3.446734 & \\
& $5 \%$ level & -2.868657 & \\
& $10 \%$ level & -2.570627 & \\
\hline \hline
\end{tabular}

"MacKinnon (1996) one-sided p-values.

\subsection{Stationary and Non-Stationary Test for Foreign Direct Investment (FDI):}

In E-views for stationary and non- stationary test, we will go to unit root test (Augmented Dickey-Fuller test statistic) Total Foreign Direct Investment at first level it not stationary but at first difference it stationary from (Result in Below Table) $p$ value is 0.00005 at $.01 \%$ it significant

Table:2 Null Hypothesis: D(FDI) has a unit root

Exogenous: Constant

Lag Length: 13 (Automatic - based on SIC, maxlag=17)

\begin{tabular}{llcc}
\hline \hline & & t-Statistic & Prob. $^{*}$ \\
\hline \hline Augmented Dickey-Fuller test statistic & & -4.319604 & 0.0005 \\
\hline Test critical values: & 1\% level & -3.446777 & \\
& $5 \%$ level & -2.868676 & \\
& $10 \%$ level & -2.570637 & \\
\hline \hline
\end{tabular}

"MacKinnon (1996) one-sided p-values.

\subsubsection{Johnson Co-integration Rank Test (Trace):}

From below Table: 3 Johnson Co-Integration test, we assumed the flowing results from the analysis. Result for short run and long run, for long run relationship Export (Nation Brand Dimensions) and Foreign Direct Investment (FDI) are significant ( Export=FDI). For short run, Foreign Direct Investment (FDI) is significant to Foreign Direct Investment (FDI), Short run Foreign Direct Investment (FDI) has effected by himself and Foreign Direct Investment to Foreign Direct Investment (FDI) significant. No short run relationship between Exports (Nation Brand Dimensions) and Foreign Direct Investment (FDI) (Export F FDI).

Table:3 Unrestricted Co-integration Rank Test (Trace)

\begin{tabular}{lcccc}
\hline \hline $\begin{array}{l}\text { Hypothesized } \\
\text { No. of CE(s) }\end{array}$ & Eigenvalue & Statistic & $\begin{array}{c}\text { Critical Value } \\
\text { Prob. }{ }^{* *}\end{array}$ \\
\hline \hline None & 0.027294 & 13.87342 & 15.49471 & 0.0865 \\
At most 1 & 0.006729 & 2.720837 & 3.841466 & 0.0990 \\
\hline \hline
\end{tabular}

Trace test indicates no co-integration at the 0.05 level 
* denotes rejection of the hypothesis at the 0.05 level

**MacKinnon-Haug-Michelis (1999) p-values

Table:4

\begin{tabular}{ccc} 
Co-integrating Equation(s): & Log likelihood & -15751.52 \\
\hline \hline Normalized co-integrating coefficients (standard error in parentheses) \\
FDI & PEXPORT \\
1.000000 & -0.098378 \\
\multicolumn{3}{c}{$(0.02387)$} \\
Adjustment coefficients (standard error in parentheses) \\
D(FDI) & -0.014756 \\
& $(0.00485)$ \\
D(EXPORT) & 0.020450 \\
& $(0.03313)$ \\
\hline \hline
\end{tabular}

\subsubsection{Co-Integration Regression Equation:}

From Table: 4 we got the following equation

$F D l_{t}=0.098378$ P-Export + 0.014756 D (FDI) $-0.020450 \mathrm{D}($ EXPORT)

$\mathrm{Se}=(0.02387)(0.00485)(0.03313)$

$\mathrm{T}=4.113 .03 \quad 0.60$

\subsubsection{Granger Causality Tests:}

From below Table: 5 , Granger Causality Test, Export (Nation Brand Dimensions) Granger to Foreign Direct Investment (FDI) and Foreign Direct Investment (FDI) is not Granger to Export (Nation Brand Dimensions)

Table: 5 Pairwise Granger Causality Tests

\begin{tabular}{lccc} 
Lags: 2 & & & \\
\hline \hline Null Hypothesis: & Obs & F-Statistic & Prob. \\
\hline \hline PEXPORT does not Granger Cause PFDI & 406 & 3.36428 & 0.0356 \\
PFDI does not Granger Cause PEXPORT & & 2.03631 & 0.1319 \\
\hline \hline Export is Granger to FDI & & & \\
FDI is not Granger to Export & & &
\end{tabular}

From below graph Export (Nation Brand Dimensions) and Foreign Direct Investment (FDI) relationship. From graph, Export in 1980 was high rather than Foreign Direct Investment.

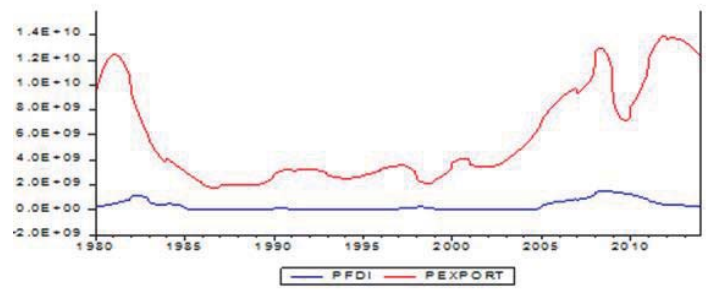

From the above graph in 1980, export of Saudi Arabia was 104411000000 US \$ and Foreign Direct Investment (FDI) was 3192313000 US \$. In 1985, export was decrease to 31243240000 US4\$ and Foreign Direct Investment (FDI) was decrease to 491422800 US\$. In 1990, total export was 47445930000 US\$ and FDI was 1861333000 US\$ it mean FDI is remaining the same. In 1995, there is no dramatically change in FDI and Export. In 2000 just export increased to 82259470000 to US\$. In 2005 export increased to 187389000000.00 US\$ and there is no change in FDI. In 2010 export jumped to 261831000000.00 US\$ and little bit changed occurred in FDI 29232710000 US\$. In 2013 export increased to 
387616000000.00 US\$ and FDI decrease to 9297694000 US\$. Conclusion from graph we assumed that there is no dramatically change in FDI but export was increased then decreased after that increased.

\section{Finding}

Finding from unit root test at first level both Export and Foreign Direct Investment are not significant, but at first difference both significant at the $0.01 \%$ level. From Johnson Co-integration Rank Test Eigenvalue 0.006729, Trace Statics value 2.720837, Critical value 3.841466 and significant value 0.0990 at $0.010 \%$. From granger cause test, Export is Granger to FDI value 0.0356 at $0.05 \%$ significant

\section{Conclusion}

This is analyzed the impact of export on FDI using time series data from 1980 to 2013 by employing E views technique. The result concluded that there is no short run relationship between Export and Foreign Direct Investment (FDI) as well as long run positive relationship between export and FDI. Whereas output has positive impact on FDI in long run but statically no significant impact on short run. Variable are non-stationary at first level but at the first difference at stationary. For short run relationship, FDI is impact FDI. From Granger Cause Test export is granger to FDI and FDI is not granger to export it mean that export can predicate FDI but FDI is not predicate export. Therefore from our result show that there is long run relationship between Export and FDI and no short run relationship between Export and FDI

\section{Acknowledgement}

The authors are thankful to the Deanship of Scientific Research, College of Business Administration Research Center at King Saud University for funding this research.

\section{References}

Krautheim, S. (2013). Export-supporting FDI. Canadian Journal of Economics/Revue canadienne d'économique, 46(4), 1571-1605.

Todo, Y. (2011). Quantitative Evaluation of the Determinants of Export and FDI: Firm-level Evidence from Japan. The World Economy, 34(3), 355-381.

Alam, A., Ullah, S., Ahmed, M., \& Gaadar, K. (2013). Nation Branding, Intellectual Property Rights and Economic Development Nexus: A Prescriptive Approach. International Review of Management and Business Research, 2(4), 1113.

Sharma, K. (2000). Export growth in India: has FDI played a role (No. 816). Center discussion paper.

Zhang, Q., \& Felmingham, B. (2001). The relationship between inward direct foreign investment and China's provincial export trade. China Economic Review, 12(1), 82-99.

Yao, S. (2006). On economic growth, FDI and exports in China. Applied Economics, 38(3), 339-351.

Koojaroenprasit, S. (2012). The impact of foreign direct investment on economic growth: A case study of South Korea. International Journal of Business and Social Science, 3(21).

Alam, A., Almotairi, M., \& H. (2012). New Prospects for foreign Investors in Saudi Arabia Journal of American Science, 10(8), 228-234. Retrieved August 25, 2012, from http://www.jofamericanscience.org/journals/am-sci/am0810/034_11214am0810_228_234.pdf

Khan, A.A. and Khan, M. (2010), Pakistan Textile Industry Facing New Challenges, Research Journal of International Studies, $14: 21$ 29.

Alguacil, M. T., Cuadros, A., \& Orts, V. (2002). Foreign direct investment, exports and domestic performance in Mexico: a causality analysis. Economics Letters, 77(3), 371-376.

Banga, R. (2006). The export-diversifying impact of Japanese and US foreign direct investments in the Indian manufacturing sector. Journal of International Business Studies, 37(4), 558-568.

Xuan, N. T., \& Xing, Y. (2008). Foreign direct investment and exports the experiences of Vietnam1. Economics of transition, 16(2), 183197.

Alam, A., Almotairi, M., \& Gaadar, K. (2013). Nation branding: An effective tool to enhance fore going direct investment (FDI) in Pakistan. Research Journal of International Studies, 25, 134-141.

Sami, J., \& Kreishan, F. (2012). FDI and export-led growth in Jordan: evidence from Co-integration and causality test. Economics Bulletin, 32(2).

Babalola, S. J., Dogon-Daji, S. D. H., \& Saka, J. O. (2012). Exports, Foreign Direct Investment and Economic Growth: An Empirical Application for Nigeria. International Journal of Economics and Finance, 4(4), p95.

Abor, J., Adjasi, C. K., \& Hayford, M. C. (2008). How does foreign direct investment affect the export decisions of firms in Ghana? African Development Review, 20(3), 446-465.

Babic, S., \& Akyel, C. (2000). Improvement in calculation of the self-and mutual inductance of thin-wall solenoids and disk coils. Magnetics, IEEE Transactions on, 36(4), 1970-1975. 